\title{
SOLA IUSTITIA
}

\author{
Rudiyanto \\ Sekolah Tinggi Theologia Abdiel \\ publicatheologia@gmail.com
}

\begin{abstract}
Capitalism seems to be the result of 500 years of Prostentantism reformation. By unraveling some bads conditions of the world today as presence of "powers" as reflected in the New Testament, and by believing that Protestantism reformation still has power in its spirits: ad fontes and semper reformanda, this article shows that we are able to put forward an intrinsic adagium of Protestantism reformation beside of sola gratia, sola fide, and sola scriptura; namely sola iustitia.
\end{abstract}

Keywords: ad fontes, kapitalisme, kekuasaan, Reformasi Protestan, semper reformanda, sola iustitia.

\section{Pendahuluan}

Pada tahun ini reformasi Protestan telah berjalan lebih dari 500 tahun. Bagi para penganutnya, reformasi Protestan adalah the Gospel rediscovered, Injil yang ditemukan kembali. Terbayang dalam benak kita adagia reformasi yang termashyur itu: sola fide, sola gratia, dan sola scriptura. Dalam dogmatika, sola fide dan sola gratia merujuk pada penyebab material reformasi Protestan, sedangkan sola scriptura merujuk pada penyebab formalnya. ${ }^{1}$

Dalam pada itu, sebenarnya yang "ditemukan kembali" adalah Injil dalam pemaknaannya yang personal. Katolisisme Abad Pertengahan berpandangan bahwa manusia diselamatkan karena tergabung dalam gereja yang melalui sakramen-sakramen berperan sebagai penyalur keselamatan. Karena di dalam gereja terdapat keselamatan maka barangsiapa bergabung dengan gereja akan beroleh keselamatan. Sebaliknya, reformasi Protestan memandang bahwa manusia adalah individu yang berhadap-hadapan seorang diri dengan Allah yang bersemayam di takhta pengadilan-Nya.

Menurut reformasi Protestan, pertama-tama individu tersebut adalah manusia berdosa (peccator), yang layak dijatuhi hukuman ilahi berupa kematian yang kekal. Akan tetapi, menurut anugerah-Nya semata Allah menyatakan individu tersebut sebagai orang

1 R.C. Sproul, "The History of the Reformation," http://www.ligonier.org/learn/articles/thehistory-of-the-reformation/ (diakses 2 Desember 2017). 
benar (iustus). Dasar dari pembenaran itu adalah Kristus yang tersalib, yang diimani oleh individu tersebut. Di kayu salib, Kristus menanggung hukuman ilahi atas dosa individu tersebut.Melalui iman, kebenaran Kristus diperhitungkan kepadanya. Dalam kata-kata Martin Luther, Jesus, tu es peccatum meum et ego sum iustitia tua; Ya Yesus, Engkau adalah dosaku dan aku dibuat menjadi kebenaran-Mu. ${ }^{2}$

Meski memaknai Injil secara personal, reformasi Protestan memiliki dampak sosial yang besar. Hal ini berkait-kelindan dengan krisis formasi sosial di Eropa Barat. Berlangsung di tengah transisi formasi sosial feodal ke formasi sosial kapitalis, reformasi Protestan mencerminkan (1) kegelisahan kaum hamba (serf) dan tani merdeka yang tercerabut dari hubungan-hubungan produksi feodal di pedesaan dan terlempar ke kotakota, dan (2) penolakan kelas menengah (borjuis) terhadap hubungan-hubungan produksi feodal yang membelenggu perkembangan tenaga-tenaga produktif baru yang bertumpu pada produksi barang jadi dan perdagangan di kota-kota. ${ }^{3}$

Dengan penekanannya pada individu, yang tanpa pengantaraan hierarki gereja harus berhadapan dengan Allah, reformasi Protestan sejalan dengan pendirian kelas menengah yang ingin mengatur kepentingan ekonomi mereka tanpa kekangan aturanaturan feodal yang justru menguntungkan kaum bangsawan. Segera dapat kita lihat bahwa sementara Katolisisme Abad Pertengahan merupakan agama Kristen dari feodalisme yang sedang berada di ambang keruntuhan, reformasi Protestan adalah agama Kristen dari kapitalisme yang sedang muncul dengan segala elan progresifnya. Dengan jalan itu reformasi Protestan turut serta dalam arak-arakan kemenangan kapitalisme atas feodalisme, yang mengubah wajah dunia secara hakiki hingga saat ini. Demikianlah "Injil yang personal" memiliki pengandaian sekaligus implikasi yang bersifat sosial.

\section{Ad Fontes, Semper Reformanda}

Lima ratus tahun setelah reformasi Protestan, kita menjumpai dunia yang kapitalistis. Kapitalisme telah menang, bahkan bukan hanya atas feodalisme, tetapi juga atas rezim-rezim kolektivisme birokratik yang diasosiasikan dengan sosialisme. Bila menurut konteksnya reformasi Protestan merupakan gugatan teologis terhadap katolisisme Abad Pertengahan, dan dengan demikian merupakan serangan di level "Struktur Atas" dari

\footnotetext{
${ }^{2}$ Lihat J. Verkuyl, Aku Percaya. Uraian tentang Injil dan Seruan untuk Percaya (Jakarta: BPK Gunung Mulia, ${ }^{16}$ 1995), 173.

${ }^{3}$ Tentang hal ini, simak Chris Harman, A People's History of the World (London \& Chicago \& Sidney: Bookmarks, 2002), 178-83.
} 
the emerging capitalism terhadap the waning feudalism maka dalam konteks masa kini tidaklah berlebihan untuk mengatakan bahwa peran historis reformasi Protestan sudah selesai. Bahkan, jangan-jangan "Injil yang ditemukan kembali," yang dibahasakan menjadi sola gratia, sola fide, dan sola scriptura, sebaik-baiknya adalah monumen-monumen ideologis yang mengharukan di satu sisi, dan seburuk-buruknya adalah bagian dari perangkat ideologis untuk melanggengkan kapitalisme di sisi lain.

Sinyalemen di atas kedengaran apatis bahkan sinis. Meski demikian, sinyalemen tersebut bisa dibaca sebagai ajakan untuk memaknai reformasi Protestan menurut spirit yang sebenarnya terkandung di dalam dirinya sendiri. Di jantung solae reformatae berdegup semangat ad fontes ("ke sumber") dan semper reformanda ("senantiasa diperbarui"). Implikasinya, bila ditilik dari peran historisnya maka solae reformatae sudah kadaluwarsa sekalipun, tidak demikian halnya dengan semangat ad fontes dan semper reformanda.

Spirit ad fontes dan semper reformanda adalah dua sisi yang saling mengandaikan. Di satu sisi, kita kembali ke sumber dilakukan bukan demi kembali ke sumber itu sendiri. Bila itu yang dilakukan, "kembali ke sumber" tidak akan membawa kita kemana-mana. Kita kembali ke sumber dalam rangka pembaruan atas reformasi Protestan yang telah menjadi monumen bahkan bagian dari perangkat ideologis dari kapitalisme. Tersirat namun jelas, pembaruan tersebut bersifat membebaskan. Bila sumber itu adalah Alkitab, maka kita kembali kepada Alkitab dalam rangka membebaskan reformasi Protestan dari status quo sebagai monumen bahkan perangkat ideologis kapitalisme.

Di sisi lain, pembaruan dilakukan bukan demi kebaruan itu sendiri. Sebaliknya, pembaruan dilakukan menurut arah tertentu. Dalam kaitan inilah kita perlu kembali ke sumber, yakni untuk mencari inspirasi bagi pembaruan itu. Bila sumber itu adalah Alkitab, maka kita perlu menggali dan menggumulinya demi mendapatkan inspirasi tentang arah pembaruan. Dalam pada itu, kita menyadari bahwa Alkitab dapat "berarti apa saja," sesuai dengan kepentingan pembacanya. Alkitab dapat dibuat berbicara untuk mendukung teologi yang konservatif dan politik yang reaksioner. Alkitab juga dapat dibuat berbicara untuk mendukung teologi yang progresif dan politik yang revolusioner. Oleh karena itu kita membutuhkan hermeneutik dengan premis nilai tertentu.

Berkenaan dengan modus produksi yang bernama kapitalisme, dengan hubunganhubungan produksinya yang eksploitatif dan sejak terkonsolidasinya hingga saat ini mengakibatkan petaka berupa penumpukan kemakmuran pada segelintir orang dengan mengorbankan sebagian terbesar umat manusia, kolonialisme, perang-perang imperialis, 
serta kerusakan alam yang semakin parah, premis nilai kita adalah keberpihakan kepada yang dieksploitasi, ditindas, dan dimarjinalkan-baik manusia, yakni perempuan dan lakilaki, maupun alam.

Dengan hermeneutik liberatif, kita kembali kepada sumber, yakni Alkitab. Dengan menggali dan menggumuli pesan liberatif Alkitab, yang timbul dan tenggelam dalam berbagai lapisan tradisi biblikal yang berasal dari berbagai kelompok kepentingan, baik rakyat maupun kaum yang berkuasa, kita dapat menetapkan arah semper reformanda dalam memperingati (dan merayakan) setengah millennium reformasi Protestan. Pesan liberatif itu merujuk pada Pemerintahan Allah, yang sejatinya merupakan proyek historis dalam rangka mewujudkan shalom, yakni perdamaian, kedamaian, kesejahteraan, dan keutuhan ciptaan. Karena shalom muskil terwujud tanpa tegaknya keadilan, maka implementasi dari pesan liberatif itu tak lain dari praksis keadilan, yakni keadilan bagi yang dieksploitasi, ditindas, dan dimarjinalkan. Bila praksis keadilan dipandang sebagai pemaknaan Injil secara sosial, kiranya tidak berlebihan bila kita menggunakan adagium sola iustititia: hanya keadilan.

\section{Kuasa-kuasa}

Salah satu tema Perjanjian Baru yang sangat menarik sekaligus relevan bagi sola iustitia adalah hubungan antara Kristus dan kuasa-kuasa. Di sejumlah tempat, tulisantulisan yang disematkan kepada rasul Paulus (corpus Paulinum) berbicara tentang kuasakuasa. Corpus Paulinum menggunakan serangkaian istilah:

- Roma 8.38-39: malaikat-malaikat (angeloi), pemerintah-pemerintah (archai), dan kuasa-kuasa (dunameis)

- 1 Korintus 2.6-8: penguasa-penguasa dunia ini (tōn archontōn tou aiōnos)

- 1 Korintus 15.24-26: segala pemerintahan, kekuasaan dan kekuatan (pasan archēn kai pasan exousian kai dunamin)

- Galatia 4:3: roh-roh dunia (ta stoicheia tou kosmou)

- Galatia 4:9: roh-roh dunia yang lemah dan miskin (ta asthenē kai ptōcha stoicheia)

- Efesus 1:20-21: segala pemerintah dan penguasa dan kekuasaan dan kerajaan dan tiaptiap nama yang dapat disebut (pasēs archēs kai exousias kai dunameōs kai kuriotētos kai pantos onomazomenou)

- Efesus 2:1: jalan dunia ini (ton aiōna tou kosmou toutou), penguasa kerajaan angkasa (ton archonta tês exousias tou aerou), roh yang sekarang sedang bekerja di antara orang-orang durhaka (tou pneumatos tou nun energountos en tois huiois tēs apatheias)

- Efesus 3:10: pemerintah-pemerintah dan penguasa-penguasa di surga (tais archais kai tais exousiais en tois epouraniois) 
- Efesus 6:12: pemerintah-pemerintah (tas archas), penguasa-penguasa (tas exousias), kuasa-kuasa dunia yang gelap ini (tous kosmokratoras tou skotous toutou), dan roh-roh jahat di udara (ta pneumatika tēs ponērias en tois epouraniois).

- Kolose 1:16: singgasana (thronoi), kerajaan (kuriotētes), pemerintah (archai), penguasa (exousiai)

- Kolose 2:8: ajaran turun-temurun (tēn paradosin tōn anthrōpōn) dan roh-roh dunia (ta stoicheia tou kosmou)

- Kolose 2:15: pemerintah-pemerintah dan penguasa-penguasa (tas archas kai tas exousias)

- Kolose 2:20: roh-roh dunia (tōn stoicheiōn tou kosmou)

Sebagian dari istilah-istilah tersebut memberi kesan bahwa kuasa-kuasa adalah makhluk-makhluk personal. Seperti misalnya, "malaikat-malaikat" (angeloi), "pemerintahpemerintah" (archai), dan "penguasa-penguasa dunia ini" (tōn archontōn tou aiōnos). Sebagian lainnya impersonal. Misalnya, "pemerintahan” (archēn), kekuasaan (exousian), kekuatan (dunamin), dan roh-roh/ pilar-pilar dunia (ta stoicheia tou kosmou).

Dalam bukunya Christ and the Powers, Hendrikus Berkhof mengemukakan bahwa Paulus meminjam gagasan dan kosa kota tentang kuasa-kuasa dari sastra apokaliptik Yahudi. Di satu sisi, Paulus sejalan dengan pandangan apokaliptik Yahudi bahwa kuasakuasa menjalankan pengaruh dan dominasi atas dunia. Di sisi lainnya, Paulus mendepersonalisasikan mereka. Artinya, sementara apokaliptik Yahudi memandang kuasakuasa sebagai makhluk-makhluk personal adikodrati, Paulus melihat mereka sebagai struktur-struktur dari eksistensi duniawi. ${ }^{4}$

Ronald J. Sider merujuk pada kesepakatan yang berkembang di kalangan para sarjana bahwa ketika Paulus berbicara tentang kuasa-kuasa, ia "merujuk baik pada struktur-struktur sosiopolitik dari masyarakat manusia, maupun pada kekuatan-kekuatan spiritual yang mendasari, ada di balik, dan dengan cara yang misterius turut membentuk struktur-struktur sosiopolitik manusia.",5

\footnotetext{
${ }^{4}$ Hendrikus Berkhof, Christ and the Powers (Scottdale: Herald Press, 1962), 14-20. Berkhof mengajukan dua argumen yang menarik. Pertama, dalam Roma 8.37-39 Paulus menempatkan Kuasa-kuasa bersama dengan hal-hal yang terbilang abstrak, seperti ruang ("baik yang di atas maupun yang di bawah") dan waktu ("baik yang ada sekarang maupun yang akan datang") sebagai realitas-realitas ciptaan yang mempengaruhi bahkan menguasai dunia. Menurut Berkhof, hal ini "mengindikasikan bahwa penekanannya terletak bukan pada natur personal-spiritual mereka, alih-alih pada ... fakta bahwa Kuasa-kuasa ini mengkondisikan kehidupan bumiah." Kedua, dalam Kol 2.8, 15-17, 20-21, "Paulus" menyejajarkan ta stoicheia tou kosmou, tidak saja dengan tas archas kai tas exousias (pemerintah-pemerintah dan penguasapenguasa), tetapi juga dengan dengan tēn paradosin tōn anthrōpōn (tradisi manusia) dan ta entalmata kai didaskalias tōn anthrōpōn (perintah-perintah dan ajaran-ajaran manusia). Ini menunjukkan bahwa Kuasakuasa adalah tradisi-tradisi, perintah-perintah, dan ajaran-ajaran yang menstrukturkan dan mengatur urusanurusan moral manusia.

${ }^{5}$ Ronald J. Sider, Christ and Violence (Scottdale/ Kitchener: Herald Press, $\left.{ }^{4} 1982\right), 50$.
} 
Untuk yang pertama Sider merujuk pada Kolose 2:8-23 yang menyatakan bahwa kuasa-kuasa "yang telah dilucuti Kristus mencakup hal-ihwal seperti filsafat, tradisi-tradisi manusia (ay 8), dan aturan-aturan keagamaan tentang hukum-hukum makanan dan

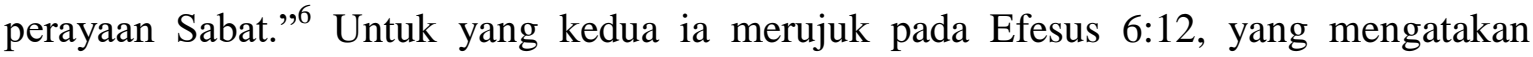
bahwa perjuangan kita "bukanlah melawan darah dan daging, tetapi melawan pemerintahpemerintah, melawan penguasa-penguasa, melawan kuasa-kuasa dunia yang gelap ini, melawan roh-roh jahat di udara."7

Menurut pendapat penulis, Sider cenderung pada penerimaan yang harafiah atas pernyataan-pernyataan corpus Paulinum tentang kuasa-kuasa. Penerimaan ini tidak lepas dari worldview kuno yang memang tercermin (juga) di dalam Alkitab. Menurut worldview ini, "segala sesuatu yang bersifat bumiah memiliki padanan sorgawinya, dan segala sesuatu yang bersifat sorgawi memiliki padanan bumiahnya." ${ }^{\circ}$ Berdasarkan worldview ini, kuasakuasa adalah struktur-struktur sosiopolitik dalam masyarakat manusia dan kekuatankekuatan spiritual yang mendasari dan turut membentuk struktur-struktur sosiopolitik tersebut. Dalam perkataan Sider,

Bagi Paulus, dalam kasus manapun, kata-kata "pemerintah-pemerintah dan penguasa-penguasa" berkonotasi baik struktur-struktur sosiopolitik yang kelihatan secara empiris dari dunia kita, maupun kekuatan-kekuatan spiritual yang tak terlihat yang bantu membentuk struktur-struktur yang kelihatan itu. ${ }^{9}$

Di lain pihak, menurut pendapat penulis, Berkhof, yang beranggapan bahwa Paulus melakukan demitologisasi atas pandangan apokaliptik Yahudi tentang kuasa-kuasa, memiliki kesulitan untuk menerima bahwa kuasa-kuasa adalah makhluk-makhluk personal-adikodrati. Kesulitan ini agaknya berkait-kelindan dengan worldview modern, yang materialistik. Sebagaimana dikatakan Walter Wink, worldview yang materialistik "telah merasuki banyak orang Kristen secara mendalam, yang menyebabkan mereka mengabaikan dimensi-dimensi spiritual dari sistem-sistem atau sumber-sumber spiritual dari iman." ${ }^{10}$ Berbeda dengan Sider yang menafsirkan kuasa-kuasa sebagai strukturstruktur sosio-politik dan makhluk-makhluk personal-adikodrati, Berkhof menafsirkan kuasa-kuasa sebagai struktur-struktur yang mengatur kehidupan manusia tanpa padanan makhluk-makhluk personal-adikodratinya. Dalam perkataan Berkhof,

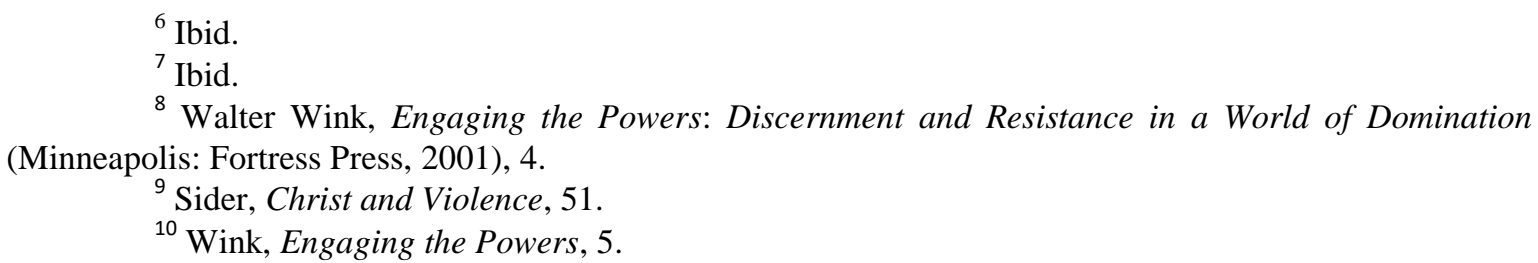


Adalah agak mengherankan bahwa dalam teologi yang lebih tua (dan faktanya dalam teologi hingga saat ini) kuasa-kuasa dipahami sebagai makhluk-makhluk yang penggambarannya dimasukkan di bawah rubrik tentang "malaikatmalaikat." Pada titik ini teologi tradisional ada dalam kesepakatan yang mengejutkan dengan riset dalam perbandingan agama ... Ada banyak kesulitan untuk mengizinkan seorang teolog yang saksama untuk menganggap serius semua yang dikatakan Paulus sebagai penggambaran tentang natur dan fungsi para malaikat ... Kesimpulannya jelas kita harus mengesampingkan pemikiran bahwa "kuasa-kuasa" dalam pemikiran Paulus adalah malaikat-malaikat. ${ }^{11}$

Penulis sendiri berpendapat bahwa sangat boleh jadi corpus Paulinum menganggap kuasa-kuasa sebagai struktur-struktur yang mengatur hidup manusia sekaligus makhlukmakhluk personal-adikodrati yang bekerja melalui struktur-struktur tersebut. Akan tetapi penulis cenderung memaknai "pasangan” tersebut merujuk pada dua sisi realitas, yakni sisi luar dan sisi dalamnya. Dalam hal ini, penulis sejalan dengan Walter Wink yang menggunakan worldview yang integral. Di satu sisi, worldview ini berupaya dengan serius untuk memahami wawasan-wawasan spiritual dari worldview kuno dengan mengafirmasi ke-dalam-an atau interioritas dari segala sesuatu; di sisi lain, worldview ini melihat realitas spiritual yang batiniah terkait begitu erat dengan perwujudan luar atau manifestasi jasmaniahnya. Sehubungan dengan kuasa-kuasa, Wink mengemukakan,

... apa yang dialami dan dinamakan sebagai "Pemerintah-pemerintah dan penguasa-penguasa" oleh orang-orang di dunia Alkitab faktanya memang riil. Mereka sedang melihat spiritualitas yang benar-benar ada di pusat institusiinstitusi politik, ekonomik, dan kultural pada zaman mereka.Aspek spiritual dari kuasa-kuasa bukanlah sekadar suatu "personifikasi" dari kualitas-kualitas institusional yang bakal eksis entah mereka dipersonifikasikan atau tidak. Sebaliknya, spiritualitas dari sebuah institusi eksis sebagai suatu aspek yang riil dari institusi tersebut, bahkan ketika ia tidak dipersepsi sedemikian. Institusiinstitusi memiliki etos spiritual yang benar-benar ada, dan bila kita mengabaikan aspek kehidupan institusional ini kita merisikokan diri kita. ${ }^{12}$

Orang-orang merasakan atau secara naluriah menangkap kualitas-kualitas spiritual dari institusi, lalu memproyeksikannya pada layar semesta. Kemudian mereka memahami kualitas-kualitas spiritual yang diproyeksikan itu sebagai kekuatan-kekuatan kosmik yang memerintah dari langit. ${ }^{13}$ Wink memberikan contoh yang sangat menarik,

Pada abad pertama, ada orang-orang Yahudi dan Kristen yang merasakan dalam kekaisaran Romawi suatu spiritualitas demonis yang mereka namakan Sammael atau Satan. Tetapi mereka menjumpai spirit ini dalam bentuk-bentuk

\footnotetext{
${ }^{11}$ Berkhof, Christ and the Powers, 19.

${ }^{12}$ Wink, Engaging the Powers, 6.

${ }^{13}$ Ibid, 7.
} 
institusional yang aktual dari kehidupan Romawi: legion-legion, gubernurgubernur, penyaliban-penyaliban, pembayaran upeti, lencana-lencana dan panji-panji Romawi, dst. Roh yang mereka rasakan eksis persis di jantung hati kekaisaran, tetapi worldview mereka memperlengkapi untuk melihat roh itu dengan merasakannya secara naluriah dan kemudian memproyeksikannya keluar, dalam bentuk yang visioner, sebagai suatu makhluk spiritual yang bersemayam di langit dan merepresentasikan Roma dewan sorgawi. ${ }^{14}$

Demikianlah, penulis berpegang pada pandangan bahwa kuasa-kuasa adalah struktur-struktur, baik aspek lahiriah maupun batiniahnya, yang mempengaruhi bahkan mendominasi kehidupan manusia, baik secara personal maupun sosial. Penulis sependapat dengan J.H. Yoder yang mengartikan struktur-struktur sebagai "pola-pola atau keteraturan yang mengatasi atau mendahului atau mengkondisikan fenomena individual yang dapat segera kita persepsikan." ${ }^{\prime \prime}$ Dalam pada itu penulis berpendapat bahwa pola-pola atau keteraturan itu memiliki spiritualitas tertentu, entah baik atau jahat, yang dirasakan oleh manusia yang hidup di dalamnya. Dalam pengalaman konkret manusia, kuasa-kuasa atau struktur-struktur dengan aspek lahiriah dan batiniahnya meliputi struktur-struktur keagamaan, intelektual, moral, dan politik. ${ }^{16}$

\section{Kristus dan Kuasa-kuasa}

Berdasarkan pernyataan-pernyataan corpus Paulinum tentang kuasa-kuasa, kita dapat membuat gambaran tentang kuasa-kuasa atau struktur-struktur sebagai berikut. ${ }^{17}$ Pertama, kuasa-kuasa diciptakan oleh Allah/ Kristus. Mereka adalah bagian dari ciptaan yang baik (lihat Kol 1.16-17). Melalui kuasa-kuasa atau struktur-struktur Allah menopang dan memelihara alam. Kuasa-kuasa juga memungkinkan keberadaan masyarakat dan sejarah. Secara negatif kita dapat mengatakan bahwa tanpa keberadaan struktur-struktur keagamaan, intelektual, moral, dan sosial, tidak akan ada masyarakat dan sejarah.

Kedua, kuasa-kuasa telah memberontak dan jatuh. Mereka tidak menerima kedudukan mereka sebagai "sekadar" sarana tatareksa ilahi. Mereka mengklaim diri sebagai Allah dan memperbudak umat manusia dan sejarah. Mereka menuntut kesetiaan tanpa syarat dari manusia, baik sebagai individu maupun masyarakat. Ketiga, syukurlah, kendati pemberontakan dan kejatuhan mereka, kuasa-kuasa tidak dapat meloloskan diri

\footnotetext{
${ }^{14}$ Ibid, 7.

${ }^{15}$ John Howard Yoder, Politics of Jesus. Vicit Agnus Noster (Grand Rapids \& Carlisle: Eerdmans/ Paternoster Press, 2002), 138.

${ }^{16}$ Ibid., 142-3.

${ }^{17}$ Untuk tiga yang pertama, lihat Yoder, Politics of Jesus, 141-4.
} 
dari kontrol Allah. Itu artinya Allah tetap dapat memakai mereka untuk kebaikan. Implikasinya, kita hidup di bawah kuasa-kuasa sementara kita menantikan karya penebusan ilahi.

Keempat, Yesus Kristus datang ke dalam dunia untuk mematahkan belenggu perbudakan kuasa-kuasa atas manusia dan alam. Dalam ketaatan kepada Allah, Yesus menghidupi kemanusiaan yang otentik. Di satu sisi Yesus "tunduk" kepada kuasa-kuasa. Artinya, Ia mengakui keniscayaan kuasa-kuasa dan tidak berpretensi untuk menghapuskan keberadaan mereka. Akan tetapi, di sisi lain Yesus menolak tuntutan kuasa-kuasa, yakni supaya Ia mengakui mereka sebagai Allah dan menaati kehendak mereka.

Alih-alih, atas nama pemerintahan Allah, yang menghendaki keadilan dan shalom bagi yang terhisap, tertindas, dan termarjinalkan, Yesus mengecam keras kuasa-kuasa yang termanifestasi dalam sistem ekonomi yang eksploitatif (“mamon”), sistem politik yang menindas ("kaisar"), dan sistem religio-kultural yang memarjinalkan ("hukum kesucian"). Ia juga merintis komunitas ("kawanan kecil”, Luk. 12:32) yang diharapkan-Nya akan menjadi sebuah masyarakat baru yang akan menghidupi suatu budaya alternatif terhadap budaya penghisapan, penindasan, dan marjinalisasi.

Kaum penguasa, yang mengekspresikan kehendak kuasa-kuasa, bereaksi keras terhadap Yesus. Mereka menangkap dan menyalibkan Yesus. Pendeknya, mereka membunuh Yesus. Akan tetapi Allah membangkitkan Yesus dari antara orang mati dan menobatkan-Nya menjadi Tuhan dan Kristus (lihat Kis 2:36), yang berkedudukan jauh lebih tinggi dari kuasa-kuasa (Ef. 1:21). Dalam terang kebangkitan, menjadi jelas bahwa melalui kematian-Nya di kayu salib Yesus mengalahkan kuasa-kuasa sebagai berikut:

- Yesus melucuti senjata (apekduomai) kuasa-kuasa. Adapun senjata kuasa-kuasa adalah "kekuatan ilusi, kemampuan mereka untuk meyakinkan manusia bahwa mereka adalah wali-wali ilahi atas dunia, kepastian yang ultimat dan arah yang ultimat, kebahagiaan yang ultimat dan kewajiban yang ultimat bagi umat manusia yang kecil dan bergantung." ${ }^{18}$ Karena senjata mereka telah dilucuti Kristus, mereka "telah kehilangan cengkeraman kuat mereka atas manusia."19

- Yesus membuat kuasa-kuasa menjadi tontonan umum (deigmatizō en parrēsia|). Di kayu salib, natur yang sesungguhnya dari kuasa-kuasa menjadi kelihatan, cetha welawela. Dengan tipu daya kuasa-kuasa telah mengklaim kemutlakan dan menuntut manusia untuk menaati mereka sepenuhnya. Sekarang, ketika Allah yang sejati menyatakan diri-Nya dalam Kristus, kuasa-kuasa bermusuhan dengan-Nya. Alih-alih bertindak sebagai alat-alat Allah, kuasa-kuasa justru menjadi seteru-seteru-Nya. ${ }^{20}$ Dengan menggelar pengadilan dusta dan menyalibkan Yesus, para representatif insaniah

\footnotetext{
${ }^{18}$ Berkhof, Christ and the Powers, 31.

19 Ibid.

${ }^{20}$ Ibid.,30-31.
} 
dari kuasa-kuasa, yakni para ahli Taurat, imam-imam kepala, tua-tua bangsa Yahudi, dan Pilatus, telah menyatakan diri mereka sebagai orang-orang yang tidak mengenal Allah (lih. 1 Kor. 2:8). Lebih jauh, dalam perjumpaan mereka dengan Allah yang sejati, terbongkar sudah bahwa kuasa-kuasa adalah ilah-ilah tetiron. ${ }^{21}$ Dalam sebuah drama kosmis yang megah, mereka telah menjadi tontonan umum.

- Yesus memimpin kuasa-kuasa dalam arak-arakan kemenangan-Nya (thriambeuō autous en autō/). Sebagaimana dikatakan Ronald Sider, kata thriambeuō merujuk pada praktikpraktik tentara Romawi. Ketika seorang jenderal Romawi telah menaklukkan bangsa lain, para penguasa bangsa tersebut harus berjalan ke Roma dengan kaki telanjang di belakang kereta-kereta perang para penakluk. ${ }^{22}$ Dalam Kristus, Allah telah menantang kuasa-kuasa, menerobos wilayah mereka, dan memperlihatkan bahwa Ia lebih kuat daripada mereka. ${ }^{23}$

Dengan kemenangan itu, Yesus mematahkan belenggu perbudakan kuasa-kuasa atas manusia bahkan alam. Sejak saat itu, setiap praksis keadilan atau perjuangan pembebas terhubung dengan kemenangan Kristus. Kuasa-kuasa, betapapun kuatnya, tidak tak terkalahkan. Oleh karena itu, tidak ada perjuangan pembebasan yang sia-sia. Kelima, Yesus Kristus menebus kuasa-kuasa. Ia telah datang tidak saja untuk mengalahkan kuasakuasa dan membebaskan manusia dan alam dari perbudakan mereka. Menurut Kolose 1:20, melalui Kristus, Allah "[berkenan, eudokēsen, dari eudokēo, lihat Kol. 1:19] memperdamaikan segala sesuatu dengan diri-Nya" (hoi autou apokallaxai ta panta eis auton). Pendamaian itu dilakukan dengan "mengadakan perdamaian melalui darah salibNya" (eirēnopoiēsas dia tou aimatos tou staurou autou), baik bagi mereka yang ada di muka bumi, maupun mereka yang ada di dalam sorga" (eite ta epi tēs gēs eite en tois ouranois).

Oleh karena menurut konteksnya (lihat Kol. 1:16-17) kuasa-kuasa terhisab dalam segala sesuatu yang diciptakan melalui Kristus, bahkan menyatu di dalam Dia, maka mereka juga menjadi sasaran karya pendamaian yang dikerjakan Yesus Kristus di atas kayu salib. Kuasa-kuasa diperdamaikan dengan Allah. Artinya, Kristus tidak mengakhiri keberadaan mereka. Justru, Ia meneguhkan keberadaan kuasa-kuasa dan mengembalikan mereka kepada fungsi yang seharusnya, yakni menjadi alat atau sarana Allah untuk kebaikan umat manusia dan alam. Dalam kata-kata Hendrikus Berkhof,

Allah memperdamaikan kuasa-kuasa — dan tidak hanya manusia-dengan diriNya melalui kematian Kristus... Disini Paulus menggunakannya dalam artian yang lebih luas, yang berarti pemulihan hubungan-hubungan yang benar. Dalam artian ini, kuasa-kuasa juga menjadi sasaran rencana penebusan Allah.

\footnotetext{
${ }^{21}$ Bnd. Ibid.,31.

${ }^{22}$ Sider, Christ and Violence, 53-54.

${ }^{23}$ Berkhof, Christ and the Powers, 31.
} 
Berkat rencana ini, mereka tidak akan lagi menjadi perintang antara manusia dan Allah, tetapi dapat dan akan kembali kepada fungsi asli mereka, yakni sebagai instrumen-instrumen persekutuan Allah dengan ciptaan-Nya. ${ }^{24}$

Kemenangan Kristus atas kuasa-kuasa dan karya pendamaian-Nya di kayu salib mengisyaratkan makna kristologis setiap perjuangan pembebasan, sekaligus fungsi kristologisnya. Karena Kristus telah memperdamaikan kuasa-kuasa dengan Allah, maka terbuka kemungkinan historis untuk membuat kuasa-kuasa melayani umat manusia dan alam. Dengan demikian, praksis keadilan bukanlah perjuangan yang menghapuskan kuasakuasa. Alih-alih, praksis keadilan adalah perjuangan yang memperbarui Kuasa-kuasa atau menggantikan suatu jenis tertentu dari manifestasi kuasa-kuasa (yang menghisap, menindas, dan memarjinalkan) dengan jenis manifestasi lain (yang lebih dapat digunakan untuk melayani umat manusia dan alam).

Dalam pada itu perlu juga kita melihat dimensi eskatologis dari kemenangan dan karya pendamaian itu. Kuasa-kuasa akan mengalami transformasi yang menyeluruh, dari seteru Allah menjadi alat/ sarana Allah untuk menyatakan kebaikan-Nya kepada manusia dan alam manakala Yesus Kristus datang untuk kedua kalinya. Dalam terang inilah kiranya kita memahami 1 Korintus 15:24. Kemudian tiba kesudahannya, yaitu bilamana Ia menyerahkan Kerajaan kepada Allah Bapa, sesudah Ia membinasakan (katargēo) segala pemerintahan, kekuasaan dan kekuatan (pasan archēn kai pasan exousian kai dunamin).

Kata yang diterjemahkan oleh TB-LAI dengan "membinasakan" adalah katargēsē (presen indikatif aktif: katargeō). Memang, kata ini bisa berarti "membinasakan. "Akan tetapi katargeō juga bisa berarti "membuat tidak efektif" atau "mengakhiri." Agaknya dua arti terakhir cocok dengan skema Paulinis tentang karya pendamaian Kristus bagi kuasakuasa. Artinya, sebelum kedatangan Kristus kembali kuasa-kuasa yang telah diperdamaikan Kristus itu masih memiliki kemungkinan historis untuk melawan Allah, yakni dengan menghisap, menindas, dan memarjinalkan manusia. Pada saat kedatangan Kristus kembali, (1) perseteruan kuasa-kuasa dengan Allah akan dibuat tidak efektif, dan/atau (2) "peran" mereka sebagai seteru Allah akan diakhiri. Alih-alih, kuasa-kuasa akan menjadi alat/ sarana Allah yang sepenuhnya efektif bagi kebaikan manusia dan alam. Dalam kata-kata Berkhof,

Kebenaran yang sama dapat dilihat dalam Efesus 1:10, dimana rencana penyelamatan Allah dinyatakan: "sebagai persiapan kegenapan waktu untuk mempersatukan di dalam Kristus sebagai kepala segala sesuatu, baik yang di

${ }^{24}$ Ibid.,33. 
surga maupun yang di bumi." kuasa-kuasa yang sekarang berusaha menjadi kepala akan ditundukkan kepada kepala mereka yang sejati, Kristus. ${ }^{25}$

\section{Sola Iustitia}

Kita sudah berupaya ber-ad fontes, kembali ke sumber, yakni Alkitab, wabil khususcorpus Paulinum. Kita telah mendengarkan suaranya tentang kuasa-kuasa. Kita juga telah mendengarkan kabar baik tentang kemenangan Kristus atas kuasa-kuasa dan karya pendamaian-Nya bagi mereka. Tantangan bagi kita sekarang adalah melaksanakan semper reformanda.

Api reformasi Protestan, bukan abunya, berhadapan dengan kapitalisme, lengkap dengan perangkat kekerasan dan perangkat hegemoniknya. Berkenaan dengan perangkat kekerasan tersebut, kita mengenal negara yang dalam epos kapitalisme merupakan pengorganisasian kekuasaan kelas kapitalis untuk mengamankan kapital, menjamin lifeline berupa eksploitasi, akumulasi, dan ekspansi, serta merepresi kelas pekerja. ${ }^{26}$ Berkenaan dengan perangkat hegemonik, kita mengenal ideologi, yang memupuk kesadaran palsu di kalangan kelas pekerja dan lapisan-lapisan tertindas lainnya, sehingga kapitalisme dianggap wajar, ketidakadilan sosial dipandang "dari sononya," sementara penghisapan, penindasan, dan marjinalisasi manusia dan alam oleh manusia tidak dipandang sebagai kejahatan serius.

Semper reformanda pada Abad XXI, termasuk di Indonesia, adalah praksis keadilan. Itu berarti perjuangan melawan kuasa-kuasa yang menubuhkan diri dalam kapitalisme berikut perangkat kekerasan dan perangkat hegemoniknya. Itu juga berarti perjuangan menggantikan formasi sosial yang paling menghisap, menindas, dan memarjinalkan itu dengan formasi sosial baru yang lebih adil dan manusiawi. Memperingati dan merayakan 500 tahun reformasi Protestan, kita diajak untuk memperjuangkan sola iustitia!

\section{Kepustakaan}

Berkhof, Hendrikus. Christ and the Powers. Scottdale: Herald Press, 1962.

Harman, Chris. A People's History of the World. London \& Chicago \& Sidney: Bookmarks, 2002.

\footnotetext{
${ }^{25}$ Ibid.

${ }^{26}$ Bnd.V.I. Lenin, Negara dan Revolusi (Djakarta: Jajasan Pembaruan, 1961), hlm. 11. Mengutip Karl Marx, Lenin menandaskan: "Menurut Marx, negara adalah suatu alat dari kekuasaan kelas, suatu alat untuk menindas kelas yang satu oleh kelas lainnya; adalah ciptaan "susunan tata-tertib", yang mengesahkan dan mengekalkan penindasan ini dengan melunakkan bentrokan antara kelas-kelas."
} 
Lenin, V.I. Negara dan Revolusi. Djakarta: Jajasan Pembaruan, 1961.

Sider, Ronald J. Christ and Violence. Scottdale/ Kitchener: Herald Press, 1982.

Verkuyl, J. Aku Percaya. Uraian tentang Injil dan Seruan untuk Percaya. Jakarta: BPK Gunung Mulia, 1995.

Wink, Walter. Engaging the Powers: Discernment and Resistance in a World of Domination. Minneapolis: Fortress Press, 2001.

Yoder, John Howard. Politics of Jesus. Vicit Agnus Noster. Grand Rapids \& Carlisle: Eerdmans/ Paternoster Press, 2002. 